\title{
Vitamin D deficiency associations with metabolic, bone turnover and adverse general health markers in community free living adults
}

Salah Gariballa* (10, Javed Yasin, Ghada Abluwi and Awad Al Essa

\begin{abstract}
Background: Although there is some evidence that vitamin D deficiency is highly prevalent in the Middle East, however its health impact is still not clear. The aim of this study was to assess the prevalence, causes and health implications of vitamin D deficiency in local United Arab Emirates (UAE) citizens.

Methods: A cross-sectional study was conducted on community free living adults living in the city of Al Ain, UAE. Following informed written consent eligible subject's blood and urine samples were taken for measurements of vitamin D $[25(\mathrm{OH}) \mathrm{D}]$, metabolic and bone turnover markers. Clinical assessment that includes general and self-rated health, muscle health, and physical activity were also performed.

Results: A total of 648 subjects (491 female) were included in this analysis. Their mean (SD) age was 38 (12) years. Mean 25(OH)D was $24 \mathrm{ng} / \mathrm{ml}$ (range: 4-67) with $286(44 \%)$ subjects found to have vitamin D deficiency ( $<20 \mathrm{ng} /$ $\mathrm{ml}), 234$ (36\%) subjects have insufficiency (20-32 ng/ml) and $128(20 \%)$ subjects have optimal concentrations (> 32 $\mathrm{ng} / \mathrm{ml})$. 25(OH)D concentrations were significantly higher in local indigenous UAE subjects compared to other Arab expatriates $(p=0.071)$. Although there were no statistically significant differences in clinical markers between groups, however, utra-sensitive C-reactive protein (us-CRP), parathyroid hormone (PTH), body mass index (BMI) and the bone markers U-PYD and PYD/CR were higher in vitamin D deficient older subjects aged $\geq 50$ years and female subjects younger than 50 years respectively compared to those with insufficiency or optimal concentrations ( $p$ value $<0.05$. Multiple logistic regression analysis revealed significant and independent association between $25(\mathrm{OH}) \mathrm{D}$ status and age and sex $(p<0.05)$.

Conclusion: Older subjects with vitamin D deficiency have increased BMI, inflammation and PTH compared with those with insufficiency or optimal concentrations. Co-existence of obesity and vitamin D deficiency may have increased adverse health effects.
\end{abstract}

Keywords: Vitamin D, Bone turnover, Inflammation, Metabolic risk factor

\footnotetext{
* Correspondence: s.gariballa@uaeu.ac.ae

Internal Medicine, Faculty of Medicine \& Health Sciences, United Arab

Emirates University, PO Box 17666, Al Ain, United Arab Emirates
}

(c) The Author(s). 2022 Open Access This article is licensed under a Creative Commons Attribution 4.0 International License, which permits use, sharing, adaptation, distribution and reproduction in any medium or format, as long as you give appropriate credit to the original author(s) and the source, provide a link to the Creative Commons licence, and indicate if changes were made. The images or other third party material in this article are included in the article's Creative Commons licence, unless indicated otherwise in a credit line to the material. If material is not included in the article's Creative Commons licence and your intended use is not permitted by statutory regulation or exceeds the permitted use, you will need to obtain permission directly from the copyright holder. To view a copy of this licence, visit http://creativecommons.org/licenses/by/4.0/. The Creative Commons Public Domain Dedication waiver (http://creativecommons.org/publicdomain/zero/1.0/) applies to the data made available in this article, unless otherwise stated in a credit line to the data. 


\section{Background}

Vitamin D an active hormone is essential for both bone and muscle health [1]. There is also mounting evidence that vitamin $\mathrm{D}$ can convey other health benefits because of the discovery that most cells and tissues in the human body contain vitamin D receptors [1]. Indeed, many observational studies have linked vitamin D deficiency or insufficiency to increased risk of cardiovascular, malignant, autoimmune and infectious diseases [1]. There is also some evidence that vitamin D deficiency is associated with increased inflammation present in obesity and related chronic diseases [2]. Humans get vitamin D from exposure to sunlight, from diet, and from dietary supplements. Other factors such as age, skin pigmentation, smoking and adiposity are known to affect vitamin D levels [1, 3]. Serum 25-hydroxyvitamin D [25(OH)D] is considered the best indicator for vitamin $\mathrm{D}$ status and a predictor of bone health and also independent predictor of risk of a number of other chronic diseases [4]. A $25(\mathrm{OH}) \mathrm{D}$ concentration of $32 \mathrm{ng} / \mathrm{mL}(80 \mathrm{nmol} / \mathrm{L})$ is proposed to be optimal for health based on variables of bone health [5]. Several studies have revealed that vitamin D deficiency is common in the Middle East and the Indian subcontinent and appears largely to be due to inadequate sun exposure [6-8]. However most of these studies so far were of small size. Furthermore, other causes and more importantly the health Implications of low vitamin D status are not clearly defined. Indeed, many studies on the relationship between low vitamin D status and bone health in south Asian population have yielded conflicting results [7, 8]. Furthermore, some cross-sectional studies comparing Caucasian and South Asian postmenopausal women point to altered metabolism of vitamin $\mathrm{D}$ in the Asian women that may protect their skeleton from bone loss. Alternatively, ethnic and/ or genetic difference may influence the capacity to synthesize vitamin D [5,9]. Although some studies have reported a high prevalence of vitamin D deficiency among UAE citizens, however the clinical benefit of optimizing vitamin D levels is still lacking. The aim of this study was to assess the prevalence, determinants and whether there is measurable increase in markers of bone turnover and adverse health outcomes in 25(OH)D deficient UAE subjects.

\section{Methods}

Details of the study participants and methods were published before [10]. Briefly participants in this study includes Emirati (UAE citizens) and expatriates from other Arab countries aged 18 years and over. They were part of a trial to assess the clinical benefit of vitamin D3 supplements. Participants were recruited from community health centers and local hospitals. The exclusion criteria include those taking calcium and/or vitamin $\mathrm{D}$ supplementation, bisphosphonates, steroid medications, hormones or diuretics. Subjects diagnosed with renal disease or stones, hypercalcaemia, and those unable to give an informed written consent were also excluded. Blood and urine samples were taken from eligible subject's for measurements of $25(\mathrm{OH}) \mathrm{D}$, biochemical metabolic and bone turnover markers and related biochemical variables following an informed written consent. Information on self-rated health, muscle pains, physical activity and dietary intakes were also collected at baseline.

Demographic, clinical and anthropometric measurements Lifestyle and health factors relevant to vitamin D deficiency were collected using a face-to-face questionnaire. Collected data included information on education and socio-economic status, current and past occupation, tobacco smoking, history of previous illness, sun exposure, body pains, use of herbal medicine, vitamin supplements, exogenous hormones for contraception and postmenopausal replacement therapy. Dietary information was obtained by a food frequency questionnaire [11]. A validated questionnaire was used to assess occupation and leisure-related physical activity [12]. Height, weight and blood pressure were measured using standard methods. Fasting blood \& urine samples were also collected. Average time of sun exposure during the day and body parts directly exposed to the sun was assessed using a face-to-face questionnaire.

\section{Biochemical and urine analysis}

Biochemical analyses included 25(OH)D, total P1NP (total Procollagen type 1 amino-terminal propeptide), Osteocalcin $(\mathrm{OCN})$ and PTH (Parathyroid Hormone) $=$ were measured using fully automated COBAS e411 analyzer that uses a patented Electro Chemi Luminescence (ECL) technology for immunoassay analysis) from ROCHE diagnostics, Manheim; U PYD = Human Pyridinoline (PYD) measured using ELISA Kit from MyBioSource, USA Cat. No. MBS030461: U DPD = Human Deoxypyridinoline (DPD) measured by ELISA Kit from MyBioSource, USA Cat. No. MBS039364; CTX-1 = Human cross-linked carboxy-terminal telopeptide of type I collagen measured using ELISA Kit Cat. No. MBS700254. Routine baseline tests including Cholesterol, Triglyceride, HbA1c, blood Glucose, hs-CRP, calcium and phosphorus, urinary creatinine were measured using Integra 400 plus Auto Analyzer from ROCHE diagnostics, Manheim.

\section{Statistical analysis}

SPSS software, version 25.0 (SPSS Inc., Chicago) was used. $25(\mathrm{OH}) \mathrm{D}$ concentrations were divided into 4 equal quartiles \& deficiency/insufficiency/optimal levels based 
on biochemical normative values accepted by many International societies [vitamin D deficiency $(<20 \mathrm{ng} /$ $\mathrm{ml})$, insufficiency $(20-32 \mathrm{ng} / \mathrm{ml})$ and optimal concentrations (> $32 \mathrm{ng} / \mathrm{ml}$ )] [5]. Analysis of variance (ANOVA) or the nonparametric Kruskal-Wallis $\mathrm{H}$ test was used to test for within and between-group differences. The influence of prognostic indicators including age, sex, body mass index, calcium \& vitamin D dietary intakes, sun exposure, smoking and physical activity on vitamin D status (deficiency vs. insufficiency vs optimal) was examined using multiple regression analysis.

\section{Results}

Six hundred forty-eight subjects (491 female) were included in this analysis. Their mean (SD) age was 38 (12) years. Mean 25(OH)D concentration was $24 \mathrm{ng} / \mathrm{ml}$ (range: 4-67) with 286 (44\%) subjects found to have vitamin D deficiency $(<20 \mathrm{ng} / \mathrm{ml}), 234(36 \%)$ subjects have insufficiency $(20-32 \mathrm{ng} / \mathrm{ml})$ and $128(20 \%)$ subjects have optimal concentrations ( $>32 \mathrm{ng} / \mathrm{ml})$.

Figure 1 shows baseline Vitamin D levels for local UAE subjects and expatriates from other Arab countries. We found statistically significant differences in $25(\mathrm{OH}) \mathrm{D}$ concentrations between ethnic Arab expatriates and local indigenous UAE subjects $(p=0.071)$.

We also found significant differences in age, sex and prevalence of diabetes mellitus between subjects with $25(\mathrm{OH}) \mathrm{D}$ deficiency compared to those with higher concentrations with higher number of females and younger subjects in those with lower concentrations (Table 1).

Subjects with vitamin D deficiency $(<20 \mathrm{ng} / \mathrm{ml})$ have increased us-CRP and PTH compared with those with insufficiency (20-32 ng/ml) or optimal concentrations (> $32 \mathrm{ng} / \mathrm{ml}$ ) (Table 2, Figs. 2, 3). Us-CRP \& PTH were higher in vitamin $\mathrm{D}$ deficient subjects particularly older ones compared with those with insufficiency or optimal concentrations (Figs. 2, 3). Figure 4 shows increased BMI for older subjects including females with vitamin D deficiency compared to those with insufficiency or optimal concentrations. 25(OH)D levels were also divided into 4 quartiles and analysed against a number of clinical and biochemical variables including inflammatory bone turn over measures (Table 3). No statistically significant differences were found between the two groups except in C-terminal telopeptide. Also, U-PYD and PYD/CR were higher in young female subjects with vitamin D deficiency compared with those with insufficiency or optimal concentrations ( $p$ value $<0.05$ ). Multiple logistic regression analysis revealed significant and independent association between vitamin $\mathrm{D}$ status and age and sex only $(p<0.05)$, (Table 4$)$. We found no statistically significant differences in clinical parameters including dietary intakes, physical activity, sun exposure or body pains and general health between subjects with highest vitamin

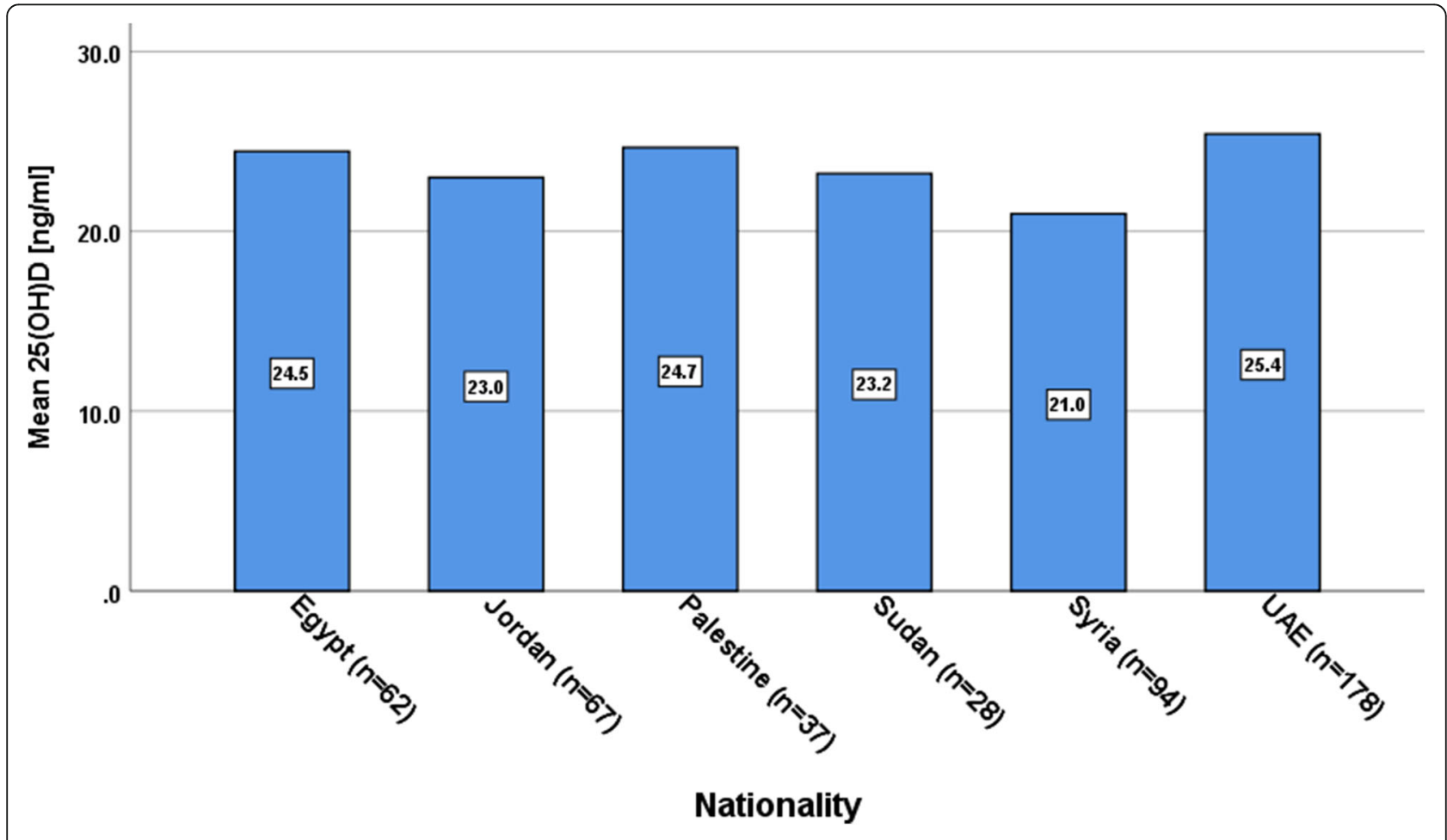

Fig. 1 Baseline 25(OH)D concentrations according to study population Nationally. $P$ value $=0.071$ for between groups difference 
Table 1 Baseline characteristics of subjects according to serum 25(OH)D concentrations [mean (SD)], unless stated otherwise

\begin{tabular}{|c|c|c|c|c|}
\hline Characteristic & $\begin{array}{l}\text { Deficiency } \\
25(\mathrm{OH}) \mathrm{D}(<20 \mathrm{ng} / \mathrm{ml})\end{array}$ & $\begin{array}{l}\text { Insufficiency } \\
25(\mathrm{OH})(20-32 \mathrm{ng} / \mathrm{ml})\end{array}$ & $\begin{array}{l}\text { Optimal } \\
25(\mathrm{OH}) \mathrm{D}(>32 \mathrm{ng} / \mathrm{ml})\end{array}$ & $P$ value \\
\hline Total number of subjects $n(\%)$ & $286(44)$ & $234(36)$ & $128(20)$ & \\
\hline Age (years)* & $36.5(12)$ & $38.7(12)$ & $41.4(13.0)$ & 0.002 \\
\hline Age < 50, n (\%) & $239(49)$ & $172(35)$ & $77(16)$ & \\
\hline Age $\geq 50, n(\%)^{*}$ & $39(32.5)$ & $45(37.5)$ & $36(30)$ & 0.000 \\
\hline \multicolumn{5}{|l|}{ Sex } \\
\hline Female* & $233(82)$ & $168(72)$ & $88(69)$ & 0.004 \\
\hline \multicolumn{5}{|l|}{ Do you smoke, n (\%) } \\
\hline Yes, on most or all days & $33(11.8)$ & $31(13.4)$ & $16(12.9)$ & \\
\hline Only occasionally & $10(3.6)$ & $10(4.3)$ & $8(6.5)$ & \\
\hline No & $236(84.6)$ & $190(82.3)$ & $100(80.6)$ & 0.723 \\
\hline \multicolumn{5}{|l|}{ Diabetes mellitus* } \\
\hline Yes & $29(11.4)$ & $26(13.3)$ & $23(23.2)$ & 0.015 \\
\hline \multicolumn{5}{|l|}{ Hypertension } \\
\hline Yes & $30(11.8)$ & $30(15.3)$ & $17(16.7)$ & 0.380 \\
\hline \multicolumn{5}{|l|}{ Angina or heart attack } \\
\hline Yes & $0(0)$ & $1(0.5)$ & $0(0)$ & 0.412 \\
\hline \multicolumn{5}{|l|}{ High cholesterol } \\
\hline Yes & $18(7.1)$ & $25(12.8)$ & $13(13.3)$ & 0.082 \\
\hline \multicolumn{5}{|l|}{ Sleep disturbance } \\
\hline Yes & $7(2.8)$ & 7 (3.6) & $8(8.3)$ & 0.058 \\
\hline \multicolumn{5}{|l|}{ Past Operation } \\
\hline Yes & $133(48.4)$ & 88 (38.8) & $44(36.1)$ & 0.017 \\
\hline
\end{tabular}

D compared to those with the lowest concentrations (Tables 5 and 6).

\section{Discussion}

Our results agree with previous studies from similar populations demonstrating a high prevalence of vitamin $\mathrm{D}$ deficiency. In addition, we found increased trends of increased BMI, inflammation and PTH in older subjects with biochemical deficiency or lowest vitamin D concentrations compared with those with biochemically normal or highest concentrations. We found no statistically significant association in biochemical bone turnover markers except for U-PYD and PYD/CR which are higher in young female subjects with vitamin D deficiency compared with those with insufficiency or optimal concentrations. In contrast no significant differences found in clinical parameters including dietary intakes, physical activity, sun exposure or body pains and general health between subjects with highest vitamin D versus those with the lowest concentrations. Vitamin D concentrations were higher in local indigenous UAE subjects compared to ethnic Arab expatriates. The association between low 25(OH)D levels and obesity (high BMI) and increased inflammation are interesting and may have public health importance particularly for our population. For example, abdominal obesity and related diabetes are very common in the UAE with the UAE having one of the highest prevalence in the World [13-16]. We have previously reported that abdominal obesity in our population is associated with increased inflammation and decreased antioxidant status [17]. The potential role of low plasma $25(\mathrm{OH}) \mathrm{D}$ concentrations as a mediator between obesity and increased risk of diabetes in the development of type 2 diabetes has been reported by several studies [18]. Experimental studies suggest 25(OH)D deficiency impairs glucose-induced insulin secretion and that insulin sensitivity may improve with $25(\mathrm{OH}) \mathrm{D}$ supplementation in patients with vitamin D deficiency [1820]. Although, hitherto studies of the effects of vitamin D supplementations on obesity associated inflammation and risk of type 2 diabetes have produced conflicting results [21-23]. A recent study has reported that vitamin D supplementation to reach and sustain 25(OH)D levels of $100-124$ and $\geq 125 \mathrm{nmol} / \mathrm{l}$ has been shown to lower the risk of progression to diabetes [24]. The results of this study encourage us to study the effects of higher 
Table 2 Clinical, anthropometric, biochemical markers of bone turnover and related variables of subjects according to serum 25(OH)D concentrations [mean (SD)] unless stated otherwise

\begin{tabular}{|c|c|c|c|c|}
\hline Characteristic & $\begin{array}{l}\text { Deficiency } \\
25(\mathrm{OH}) \mathrm{D}(<20 \mathrm{ng} / \mathrm{ml})\end{array}$ & $\begin{array}{l}\text { Insufficiency } \\
25(\mathrm{OH}) \mathrm{D}(20-32 \mathrm{ng} / \mathrm{ml})\end{array}$ & $\begin{array}{l}\text { Optimal } \\
25(\mathrm{OH}) \mathrm{D}(>32 \mathrm{ng} / \mathrm{ml})\end{array}$ & $P$ value \\
\hline Weight (Kg) & $77.8(18)$ & $78.76(18)$ & $80.81(18)$ & 0.313 \\
\hline $\mathrm{BMI}$ & $29.47(11)$ & $29.13(14)$ & $28.89(5)$ & 0.910 \\
\hline $\mathrm{SBP}(\mathrm{mmHg})$ & $122.8(17)$ & $125.7(16)$ & $124.2(14)$ & 0.320 \\
\hline $\mathrm{DBP}(\mathrm{mmHg}) *$ & $74.84(8)$ & $77.5(8)$ & $76.94(8)$ & $0.012^{*}$ \\
\hline $\mathrm{HbA} 1 \mathrm{C}(\%)$ & $5.77(0.97)$ & $5.63(0.90)$ & $5.79(1.13)$ & 0.175 \\
\hline Glucose $(\mathrm{mmol} / \mathrm{L})$ & $6.25(2.67)$ & $6.03(2.44)$ & $6.22(2.73)$ & 0.614 \\
\hline Hs CRP (mg/L) & $3.68(4.34)$ & $3.36(3.42)$ & $3.10(2.97)$ & 0.326 \\
\hline Cholesterol (mmol/L) & $4.82(0.99)$ & $4.88(0.93)$ & $4.78(0.95)$ & 0.598 \\
\hline $\mathrm{HDL}(\mathrm{mmol} / \mathrm{L})$ & $1.28(0.73)$ & $1.26(0.39)$ & $1.26(0.36)$ & 0.911 \\
\hline $\mathrm{LDL}(\mathrm{mmol} / \mathrm{L})$ & $3.26(0.92)$ & $3.26(0.86)$ & $3.11(0.87)$ & 0.246 \\
\hline Triglycerides (mmol/L) & $1.34(0.90)$ & $1.45(1.07)$ & $1.39(1.19)$ & 0.457 \\
\hline Calcium (mmol/L) & $2.29(0.11)$ & $2.28(0.99)$ & $2.29(0.11)$ & 0.679 \\
\hline Phosphate (mmol/L) & $1.18(0.20)$ & $1.21(0.17)$ & $1.18(0.19)$ & 0.084 \\
\hline Osteocalcin (ng/ml) & $18.0(7.07)$ & $18.11(8.43)$ & $17.97(12.1)$ & 0.986 \\
\hline PTH (pg/ml) & $29.52(18.5$ & $28.72(15.35)$ & $32.37(48.2)$ & 0.441 \\
\hline P1NP (ng/ml) & $50.22(23)$ & $47.71(21.48)$ & $50.85(59.8)$ & 0.600 \\
\hline CTX1 (ng/ml) & $10.17(7.3)$ & $11.83(7.58)$ & $10.41(6.56)$ & 0.212 \\
\hline U-DPD (nmol/L) & $95.57(47.8)$ & $90.81(44.9)$ & $93.89(48.6)$ & 0.837 \\
\hline U-PYD (nmol/L) & $230.14(89.6)$ & $234.11(104)$ & $217.38(93)$ & 0.670 \\
\hline $\mathrm{PYD} / \mathrm{Cr}(\mathrm{nmol} / \mathrm{mmol})$ & $24.14(11.6)$ & $24.34(12)$ & $22.61(11.8)$ & 0.738 \\
\hline DPD/Cr (nmol/mmol) & $10.29(6.03)$ & $9.63(5.66)$ & $10.13(6.5)$ & 0.806 \\
\hline
\end{tabular}

$* P<0.05$
Abbreviations: HDL High density lipoprotein, $L D L$ Low density lipoprotein, HsCRP High sensitivity C reactive protein, $P$ TH Parathyroid Hormone, $P 1 N P$ Procollagen type-1 N-terminal propeptide, CTX1 C-terminal telopeptide of type -1 collagen, U DPD Urine Deoxypyridinoline, U PYD Urine Pyridinoloine, OSTEO Osteocalcin

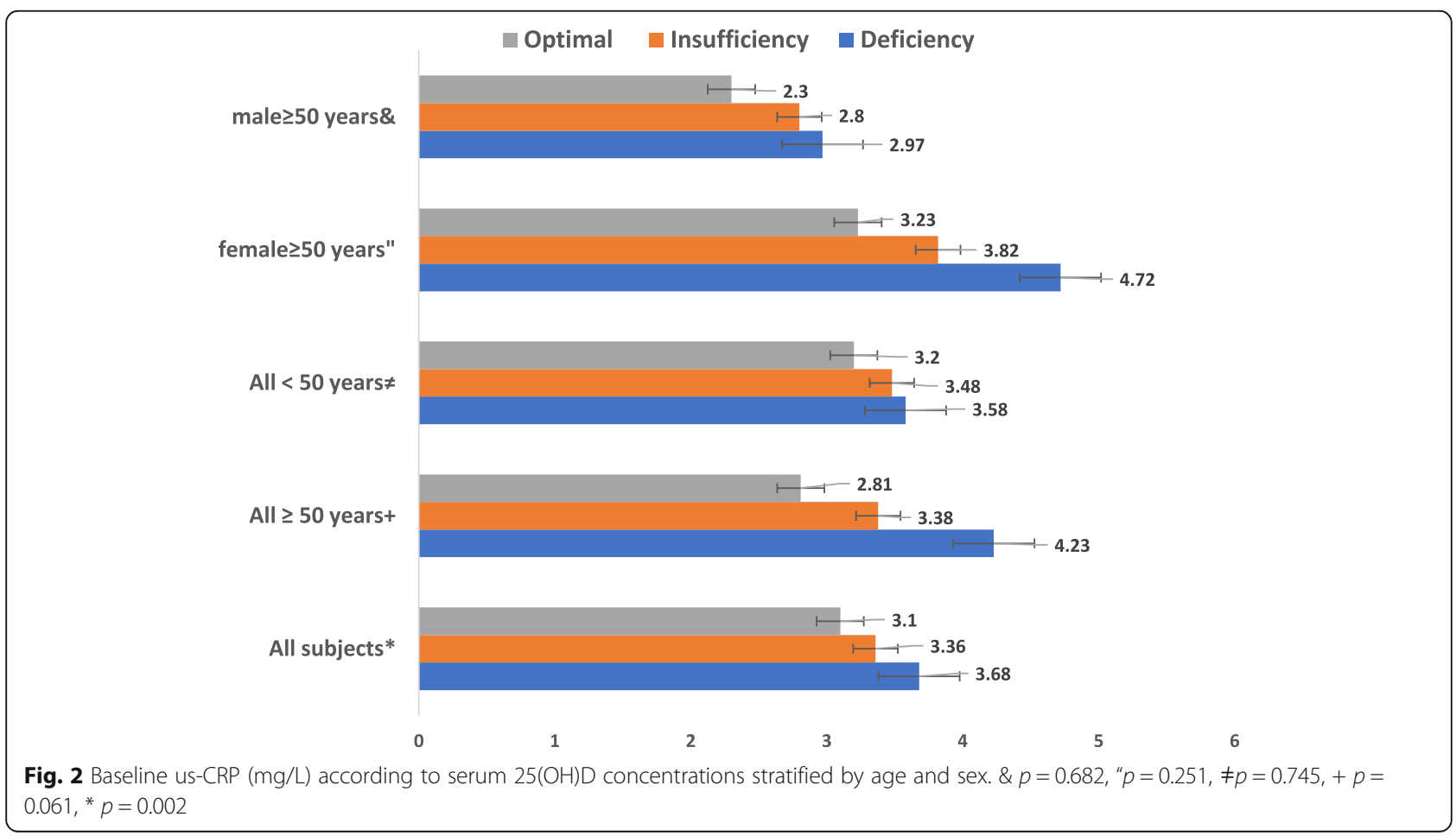




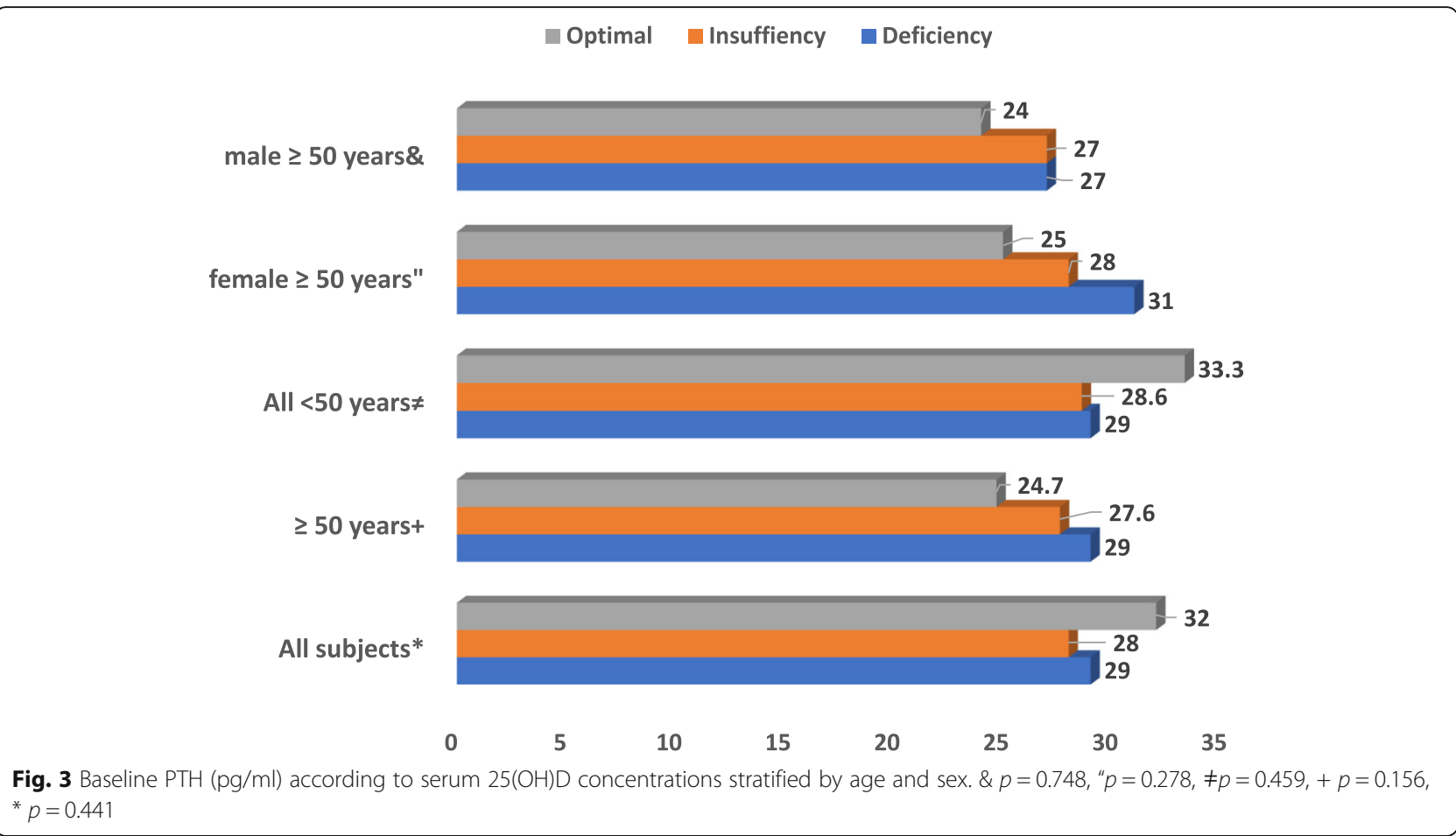

dose, frequency and duration of vitamin D supplementation to reach and sustained higher levels to find out if indeed this will lead to a clinical benefit in our high-risk population. Currently ongoing trial results should provide us with more definitive answers.
The cutaneous manufacturing of $25(\mathrm{OH}) \mathrm{D}$ depends on a number of factors including age, skin color/pigmentation, season, latitude and exposure to sunlight including use of sunscreen. Furthermore, darker skin people require higher doses of sun exposure/ UV-B light to reach

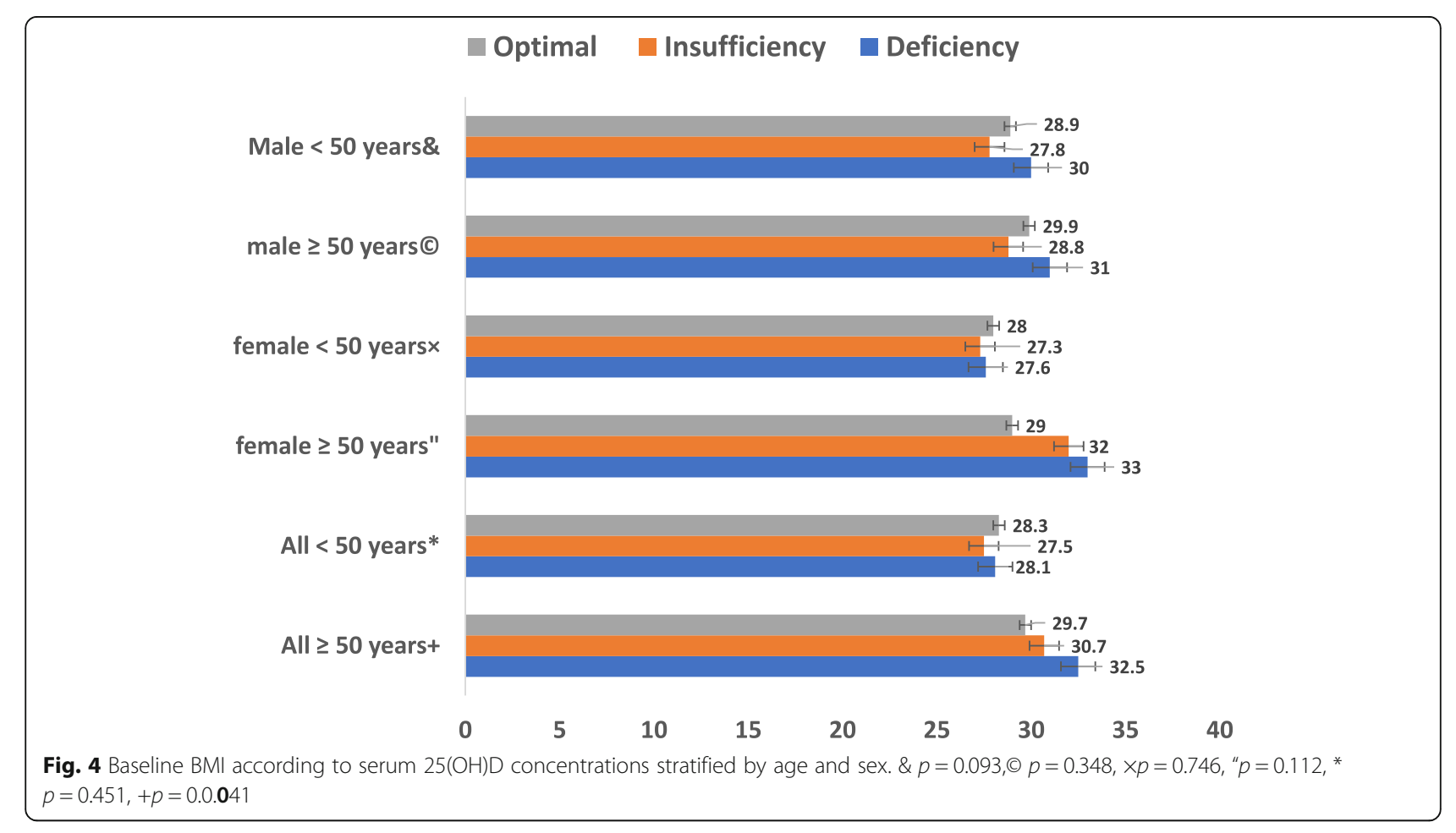


Table 3 Anthropometric, biochemical markers of bone turnover and related variables of subjects according to serum 25(OH)D concentrations divided into 4 equal quartiles [mean (SD)]

\begin{tabular}{|c|c|c|c|c|c|}
\hline Variable & $\begin{array}{l}\text { 1st quartile } \\
25(\mathrm{OH}) \mathrm{D} \\
\leq 15 \mathrm{ng} / \mathrm{ml}\end{array}$ & $\begin{array}{l}\text { 2nd quartile } 25(\mathrm{OH}) \mathrm{D} \\
=15.1-21.9 \mathrm{ng} / \mathrm{ml}\end{array}$ & $\begin{array}{l}\text { 3nd quartile } 25(\mathrm{OH}) \mathrm{D} \\
=22-30 \mathrm{ng} / \mathrm{ml}\end{array}$ & $\begin{array}{l}\text { 4th quartile } 25(\mathrm{OH}) \mathrm{D} \\
>31.1 \mathrm{ng} / \mathrm{ml}\end{array}$ & $P$ value \\
\hline Weight (Kg) & $77.26(17)$ & $79.51(18)$ & $78.50(17)$ & $79.67(17)$ & 0.622 \\
\hline BMI & $28.93(5)$ & $28.98(5)$ & $28.07(4)$ & $28.31(5)$ & 0.423 \\
\hline $\mathrm{SBP}(\mathrm{mmHg})$ & $121.83(16)$ & $125.62(18)$ & $124.27(15)$ & $124.67(13)$ & 0.397 \\
\hline $\mathrm{DBP}(\mathrm{mmHg})$ & 74.67 (8) & $75.78(7)$ & $77.34(8)$ & $77.06(7)$ & 0.089 \\
\hline $\mathrm{HbA1C}(\%)$ & $5.72(0.9)$ & $5.84(1)$ & $5.60(0.7)$ & $5.72(1)$ & 0.196 \\
\hline Glucose (mmol/L) & $6.14(2)$ & $6.48(3)$ & $6.02(1)$ & $6.00(2)$ & 0.321 \\
\hline Hs CRP (mg/L) & $3.97(4)$ & $3.38(3)$ & $3.33(3)$ & $3.10(2)$ & 0.198 \\
\hline Cholesterol (mmol/L) & $4.79(0.9)$ & $4.88(0.9)$ & $4.88(0.9)$ & $4.75(0.9)$ & 0.541 \\
\hline $\mathrm{HDL}(\mathrm{mmol} / \mathrm{L})$ & $1.32(0.9)$ & $1.23(0.4)$ & $1.27(0.3)$ & $1.25(0.3)$ & 0.494 \\
\hline LDL (mmol/L) & $3.22(0.9)$ & $3.31(0.8)$ & $3.26(0.8)$ & $3.11(0.8)$ & 0.239 \\
\hline Triglycerides (mmol/L) & $1.27(0.8)$ & $1.48(1)$ & $1.44(1)$ & $1.36(1)$ & 0.249 \\
\hline Calcium (mmol/L) & $2.28(0.1)$ & $2.29(0.1)$ & $2.28(0.1)$ & $2.28(0.1)$ & 0.881 \\
\hline Phosphate (mmol/L) & $1.17(0.2)$ & $1.19(0.1)$ & $1.21(0.1)$ & $1.18(0.1)$ & 0.369 \\
\hline Osteocalcin (ng/ml) & $17.92(6)$ & $18.10(7)$ & $17.45(7)$ & $18.66(11)$ & 0.666 \\
\hline PTH $(p g / m l)$ & $28.70(18)$ & $30.62(18)$ & $27.73(15)$ & $32.10(43)$ & 0.446 \\
\hline P1NP (ng/ml) & $50.10(23)$ & $49.90(22)$ & $46.75(21)$ & $50.98(53)$ & 0.682 \\
\hline CTX1 (ng/ml) * & $11.58(8)$ & $9.12(5)$ & $12.45(7)$ & $10.41(6)$ & $0.034^{*}$ \\
\hline U-DPD (nmol/L) & $101.53(45)$ & $89.08(47)$ & $88.53(43)$ & $97.39(50)$ & 0.526 \\
\hline U-PYD (nmol/L) & $232.94(88)$ & $234.62(89)$ & $221.59(103)$ & $227.71(100)$ & 0.914 \\
\hline $\mathrm{PYD} / \mathrm{Cr}(\mathrm{nmol} / \mathrm{mmol})$ & $24.43(10)$ & $24.55(12)$ & $22.94(11)$ & $23.76(12)$ & 0.910 \\
\hline $\mathrm{DPD} / \mathrm{Cr}(\mathrm{nmol} / \mathrm{mmol})$ & $11.05(5)$ & $9.39(5)$ & $9.44(5)$ & $10.50(6)$ & 0.534 \\
\hline
\end{tabular}

their maximum capacity of $25 \mathrm{OHD}$ production in the skin. Studies have reported that veiled Arabian women have lower 25OHD concentrations than non-veiled women [7]. We found no statistically significant differences in $25(\mathrm{OH}) \mathrm{D}$ concentrations between ethnic Arab

Table 4 Multiple logistic regression analysis of the influence of some clinical prognostic variables on vitamin D status (deficiency vs. insufficiency/optimal) of study population

\begin{tabular}{lll}
\hline Variable & Odd ratio $(\mathbf{9 5 \%}$ C.I) & $\boldsymbol{P}$ value \\
\hline Age (years) & $1.023(1.004-1.041)$ & .015 \\
Sex (male/female) & $.478(.297-.770)$ & .002 \\
BMI & $.964(.926-1.003)$ & .073 \\
Sun exposure & $1.012(.929-1.102)$ & .791 \\
Diet & $1.023(.951-1.101)$ & .545 \\
Physical activity & $1.065(.787-1.441)$ & .684 \\
Smoking & $1.034(.783-1.367)$ & .812 \\
Diabetes mellitus & $1.143(.634-2.061)$ & .656 \\
Hs CRP (mg/L) & $.996(.946-1.048)$ & .876 \\
PTH (pg/ml) & $1.001(.994-1.008)$ & .718 \\
\hline${ }^{* P<0.05}$ & &
\end{tabular}

expatriates and local indigenous Emirati subjects despite apparent differences in dress and behavioral life style practices including diet and physical activity between the two groups. A previous study of 259 women from the same population found no significant differences in $25(\mathrm{OH}) \mathrm{D}$ concentration between women who covered their whole body and those exposed their face and hands. However, the same study showed significantly lower 25(OH)D concentrations between local Emirati women and 7 non-Arab Caucasian ladies who dressed in a Western style [7]. Recent evidence suggest that sunlight exposure plays a much smaller role in maintaining vitamin D status in Asian population because of pigmented skin and/or altered metabolism and may therefore need increased oral intake of calcium and vitamin D [8]. In contrast to a previous study from the same population, we found no statistically significant association between vitamin $\mathrm{D}$ concentrations and dietary intakes [7]. A 1-year longitudinal study of 35 South Asian and 105 Caucasian women reported dietary intake of vitamin D had no impact on 25OHD levels [25]. Differences may be due to different dietary assessment tools used in different studies and/or inherent recall biases in dietary intakes assessment. 
Table 5 Self-rated health, body pains and sun exposure of subjects according to serum 25(OH)D concentrations [n(\%)]

\begin{tabular}{|c|c|c|c|c|}
\hline Characteristic & $\begin{array}{l}\text { Deficiency } \\
25(\mathrm{OH}) \mathrm{D}(<20 \mathrm{ng} / \mathrm{ml})\end{array}$ & $\begin{array}{l}\text { Insufficiency } \\
25(\mathrm{OH}) \mathrm{D}(20-32 \mathrm{ng} / \mathrm{ml})\end{array}$ & $\begin{array}{l}\text { Optimal } \\
25(\mathrm{OH}) \mathrm{D}(>32 \mathrm{ng} / \mathrm{ml})\end{array}$ & $P$ value \\
\hline \multicolumn{5}{|l|}{ Body pain $\mathrm{n}(\%)$} \\
\hline No & $182(64.3)$ & $138(59.7)$ & $80(63)$ & \\
\hline Yes & $101(35.7)$ & $93(40.3)$ & $47(37)$ & 0,562 \\
\hline \multicolumn{5}{|l|}{ General health n (\%) } \\
\hline Excellent & $42(14.9)$ & $32(13.9)$ & $16(12.6)$ & \\
\hline Good & $178(63.3)$ & $140(60.6)$ & 76 (59.8) & \\
\hline Fair & $33(11.7)$ & $26(11.3)$ & $13(10.2)$ & \\
\hline Poor & $16(5.7)$ & $23(10.0)$ & $15(11.8)$ & \\
\hline Do not know & $12(4.3)$ & $10(4.3)$ & $7(5.5)$ & 0.231 \\
\hline \multicolumn{5}{|c|}{ Sun exposure: usual clothing when outdoors in the sun between 10:00 AM and 2:00 PM during each season during the past 12 months, $\mathrm{n}(\%)$} \\
\hline Shorts \& brief top with shoulders exposed & $1(0.4)$ & $1(0)$ & $1(1.0)$ & \\
\hline Short and T-shirt or similar top & $1(0.4)$ & $1(0)$ & $1(1.0)$ & \\
\hline Shorts and long sleeve & $3(1.2)$ & $2(0)$ & $0(0)$ & \\
\hline Long pant and T-shirt or similar top & $176(69.8)$ & $117(0)$ & $51(53.1)$ & \\
\hline Long pants and long sleeves & $4(1.6)$ & $1(0)$ & $2(2.1)$ & 0.319 \\
\hline \multicolumn{5}{|c|}{ Sunscreen: describe your usual use of sunscreen when outdoors } \\
\hline I almost never used sunscreen & $5(2.0)$ & $4(0)$ & $5(5.2)$ & \\
\hline I used it occasionally & $1(0.4)$ & $0(0)$ & $1(1.0)$ & \\
\hline I used it somewhat regularly & $7(2.8)$ & $20(0)$ & $13(13.5)$ & \\
\hline I used it most of the time & $0(0)$ & $1(0)$ & $0(0)$ & \\
\hline I used it all the time & $1(0.4)$ & $1(0)$ & $0(0)$ & 0.856 \\
\hline
\end{tabular}

${ }^{*} P$ value $<0.05$

Table 6 Physical activity of subjects according to serum 25(OH)D concentrations [n (\%)]

\begin{tabular}{|c|c|c|c|c|}
\hline Characteristic & $\begin{array}{l}\text { Deficiency } \\
25(\mathrm{OH}) \mathrm{D}(<20 \mathrm{ng} / \mathrm{ml})\end{array}$ & $\begin{array}{l}\text { Insufficiency } \\
\text { 25(OH)D (20-32 ng/ml) }\end{array}$ & $\begin{array}{l}\text { Optimal } \\
25(\mathrm{OH}) \mathrm{D}(>32 \mathrm{ng} / \mathrm{ml})\end{array}$ & $P$ value \\
\hline \multicolumn{5}{|c|}{ Occupation: physical activity? n (\%) } \\
\hline Not very active & $33(11.8)$ & $39(17.0)$ & $17(13.8)$ & \\
\hline Moderately active & $157(56.1)$ & $120(52.2)$ & $62(50.4)$ & \\
\hline Very active & $87(31.1)$ & $67(29.1)$ & $41(33.3)$ & \\
\hline Not working & $3(1.1)$ & $4(1.7)$ & $3(2.4)$ & 0.464 \\
\hline \multicolumn{5}{|l|}{ Leisure: physical activity? n (\%) } \\
\hline Not very active & $54(19.1)$ & $50(21.7)$ & $33(26.2)$ & \\
\hline Moderately active & $193(68.4)$ & $140(60.9)$ & $76(60.3)$ & \\
\hline Very active & $35(12.4)$ & $40(17.4)$ & $17(13.5)$ & 0.447 \\
\hline \multicolumn{5}{|l|}{ Physical activity till sweating n (\%) } \\
\hline Less than once per week & $108(38.8)$ & $102(44.5)$ & $58(46.4)$ & \\
\hline 1-2 times per week & $54(19.4)$ & $43(18.8)$ & $20(16.0)$ & \\
\hline 3-4 times per week & $47(16.9)$ & $34(14.8)$ & $22(17.6)$ & \\
\hline 5-6 times per week & $43(15.5)$ & $29(12.7)$ & $15(12.0)$ & \\
\hline 7-8 times per week & $23(8.3)$ & $20(8.7)$ & $9(7.2)$ & \\
\hline More than 8 times per week & $3(1.1)$ & $1(0.4)$ & $1(0.8)$ & 0.354 \\
\hline
\end{tabular}


Vitamin D is also essential for both bone and muscle health. Although 2 previous studies in Arab men and women reported associations between $25(\mathrm{OH}) \mathrm{D}$ deficiency and increased muscle and back pains in the Saudi women and back aches disappeared with normalization of $25(\mathrm{OH}) \mathrm{D}$ levels, we did not however find statistically significant association in body pains and general health between subjects with highest $25(\mathrm{OH}) \mathrm{D}$ versus those with the lowest concentrations. A meta-analysis of studies on effects of vitamin D on muscle strength, mass and power reported a weak, but positive effects with 25(OH)D supplementations [26]. The effect was only evident in people aged 65 years or older [25]. However, a recent randomized controlled trial of 4 months vitamin D supplementation of 417 vitamin D deficient men and women aged $40-80$ years from Norway did not show improvement in muscle strength [27]. The authors suggested age difference between the two study populations might be the reason for the discrepancy between the meta-analysis findings and their study. This may also be the reason for the lack of an association in our study in body pains and general health between subjects with highest 25(OH)D compared to those with the lowest concentrations. Given the known link between 25 $(\mathrm{OH}) \mathrm{D}$ and muscle, health further research is needed to explore the relationship between vitamin D metabolism and musculoskeletal health.

Out of many bone turnover markers we measured in both blood and urine, only U-PYD and PYD/CR were significantly higher in young female subjects with $25(\mathrm{OH}) \mathrm{D}$ deficiency compared with those with insufficiency or optimal concentrations $(p$ value $<0.05)$. Although we found a trend of increased PTH in both older male and females subjects with 25(OH)D deficiency $(<$ $20 \mathrm{ng} / \mathrm{ml}$ ) compared with those with insufficiency (20$32 \mathrm{ng} / \mathrm{ml}$ ) or optimal concentrations (>32 ng/ml), but these differences did not reach statistical significance. However, this does point to a degree of secondary hyperparathyroidism as a result of increased bone turnover associated with 25(OH)D deficiency. High PTH increase bone turnover and may exert inhibitory effects on bone growth by increasing the production of IGFBP and reducing IGF-1 [7]. Unfortunately, we did not measure either IGFBP or IGF-1. There is also some evidence that the relationship between PTH and $25(\mathrm{OH}) \mathrm{D}$ is not linear [28]. More importantly however, the threshold of $25(\mathrm{OH}) \mathrm{D}$ level in relation to bone turnover and other health outcomes for our citizens and much other similar Asian population is not definitely known. Research is clearly required to examine this important latter question.

Although we found higher concentrations of us-CRP in some vitamin D deficient subjects, however, the relationship between $25(\mathrm{OH}) \mathrm{D}$ and inflammatory markers has not been consistent [29]. A meta-analysis of trials that examined the impact of vitamin D supplementation on inflammatory biomarkers have also reported conflicting results $[30,31]$. This was because some of the trials included in the meta-analysis were of small sample size with participants of wider age groups and comorbidities [29]. Larger studies with longer follow up may help to clarify the relationship between vitamin D levels and inflammatory pathways.

\section{Conclusion}

Our results point to an association between 25OHD deficiency and increased metabolic risk factors. Current evidence from other population also show a plausible link between low 25OHD and obesity and associated inflammation and type 2 diabetes, but whether this association is causal remains unclear. Ongoing trial results should provide us with more answers to these important questions. However, given the co-existence of pathologically high prevalence of 25OHD deficiency and obesity in our population the potential benefits of optimizing vitamin D status is likely to have significant health implications. Hence the need for this research in ours and other similar high-risk populations.

\section{Abbreviations \\ HDL: High density lipoprotein; LDL: Low density lipoprotein; HsCRP: High sensitivity $\mathrm{C}$ reactive protein; PTH: Parathyroid Hormone; P1NP: Procollagen type-1 N-terminal propeptide; CTX1: C-terminal telopeptide of type -1 collagen; U DPD: Urine Deoxypyridinoline; U PYD: Urine Pyridinoloine; OSTEO: Osteocalcin}

\section{Acknowledgements \\ None.}

Authors' contributions

SG wrote the first draft, analyzed and interpreted the data. JA \& AE contributed to the analysis, and interpretation of data. GA contributed to data entry, presentation and analysis. All authors contributed to the design and running of study, writing of the manuscript and the discussion. All authors read and approved the final manuscript.

\section{Funding}

This study was supported by a grant from United Arab Emirates University project Grant. The funder had no role on the study design, data analysis, interpretation and writing of the manuscript.

Availability of data and materials

Data is available upon request to the corresponding author.

\section{Declarations}

Ethics approval and consent to participate

Al Ain Medical District Human research ethics committee approved the study by (NP-17-11). An informed written consent was obtained from all patients recruited to this study.

Consent for publication

Not applicable.

\section{Competing interests}

The authors declare that they have no financial or non-financial competing interest or conflict of interest. 
Received: 21 September 2020 Accepted: 22 December 2021

Published online: 06 January 2022

\section{References}

1. Holick MF. Vitamin D deficiency. N Engl J Med. 2007;357:266-81.

2. Fu J, Han L, Zhao Y, Li G, Zhu Y, Li Y, et al. Vitamin D levels are associated with metabolic syndrome in adolescents and young adults: the BCAMS study. Clin Nutr. 2019;38:2161-7.

3. Chu MP, Alagiakrishnan K, Sadowski C. The cure of ageing: vitamin D--magic or myth? Postgrad Med J. 2010;86(1020):608-16.

4. Zerwekh JE. Blood biomarkers of vitamin D status. Am J Clin Nutr. 2008; 87(suppl):1087S-91S.

5. Farrar MD, Kift R, Felton SJ, Berry JL, Durkin MT, Allan D, et al. Recommended summer sunlight exposure amounts fail to produce sufficient vitamin D status in UK adults of south Asian origin. Am J Clin Nutr. 2011;94:1219-24.

6. Saadi H, Dawodu A, Afandi B, Zayed R, Benedict S, Ngelkerke N. Efficacy of daily and monthly high-dose calciferol in vitamin $\mathrm{D}$ deficient nulliparous and lactating women. Am J Clin Nutr. 2007:85:1565-71.

7. Saadi H, Nagelkerke N, Benedict S, Qazaq H, et al. Predictors and relationship of serum 25 hydroxyvitamin $\mathrm{D}$ concentration with bone turnover markers, bone mineral density and vitamin D receptor genotype in Emirati women. Bone. 2006;39:1136-43.

8. Ritu G, Gupta A. Vitamin D deficiency in India: prevalence, causalities and interventions. Nutrients. 2014;6(2):729-75.

9. Holvik K, Meyer HE, Søgaard AJ, Selmer R, Haug E, Falch JA. Biochemical markers of bone turnover and their relation to forearm bone mineral density in persons of Pakistani and Norwegian background living in Oslo Norway. Eur J Endocrinol. 2006;155:693-9.

10. Gariballa S, Shah I, Yasin J, Alessa A. Vitamin D [25(OH)D] metabolites and epimers in obese subject: interaction and correlations with adverse metabolic health risk factors. J Steroid Biochem Mol Biol. 2022;215:106023.

11. European Food Safety European Food Safety Authority (EFSA). General principles for the collection of national food consumption data in the view of a pan-European dietary survey. EFSA. 2009;7(12):1435 http://www.efsa. europa.eu/de/efsajournal/doc/1435.pdf.

12. Gariballa, Afandi B, Abu Haltem A, Yassin J, Alessa A. Effect of antioxidants and B-group vitamins on risk of infections in patients with type 2 diabetes mellitus. Nutrients. 2013;5(3):711-24.

13. WHO Consultation on Obesity (1999: Geneva, Switzerland) \& World Health Organization. Obesity: preventing and managing the global epidemic: report of a WHO consultation. World Health Organization; 2000. https://a pps.who.int/iris/handle/10665/42330.

14. The Report of a British Nutrition Foundation Task Force. Cardiovascular disease, diet, nutrition and emerging risk factors. Oxford: Balckwell Publishing Ltd; 2005

15. Gariballa S, Alkaabi J, Yasin J, Al EA. Oxidative damage and associated inflammatory risk factors in obese Emirati women. Body mass index versus waist circumference. Saudi Med J. 2017;38(9):960-4.

16. Malik A, Babir A, Abi Saab B, Roglic G, King H. Glucose intolerance and associated factors in the UAE. Diabetes Res Clin Pract. 2005;69:188-95.

17. Gariballa S, Kosanovic M, Yasin J, Essa AE. Oxidative damage and inflammation in obese diabetic emirati subjects. Nutrients. 2014;6(11):487280.

18. Afzal S, Brøndum-Jacobsen P, Bojesen SE, Nordestgaard BG. Vitamin D concentration, obesity, and risk of diabetes: a mendelian randomisation study. Lancet Diabetes Endocrinol. 2014;2(4):298-306.

19. Norman AW, Frankel JB, Heldt AM, Grodsky GM. Vitamin D deficiency inhibits pancreatic secretion of insulin. Science. 1980;209:823-5.

20. Cade C, Norman AW. Vitamin D3 improves impaired glucose tolerance and insulin secretion in the vitamin D-deficient rat in vivo. Endocrinology. 1986; 119:84-90.

21. Jorde R, Sneve M, Torjesen PA, Figenschau Y, Grransson LG, Omdal R. No effect of supplementation with cholecalciferol on cytokines and markers of inflammation in overweight and obese subjects. Cytokine. 2010;50:175-80.

22. Beilfuss J, Berg V, Sneve M, Jorde R, Kamycheva E. Effectsofa1-year supplementation with cholecalciferol on interleukin-6, tumor necrosis factor-alpha and insulin resistance in overweight and obese subjects. Cytokine. 2012;60:870-4.

23. Wamberg L, Kampmann U, Stødkilde-Jørgensen H, Rejnmark L, Pedersen SB, Richelsen B. Effects of vitamin D supplementation on body fat accumulation, inflammation, and metabolic risk factors in obese adults with ow vitamin D levels - results from a randomized trial. Eur J Intern Med. 2013;24:644-9.

24. Dawson-Hughes B, Staten MA, Knowler WC, Nelson J, Vickery EM, LeBlanc ES, et al. Intratrial exposure to vitamin D and new-onset diabetes among adults with prediabetes: a secondary analysis from the vitamin D and type 2 diabetes (D2d) study. Diabetes Care. 2020;43(12):2916-22.

25. Darling AL, Hart KH, Macdonald HM, Horton K, Kang'ombe AR, Berry JL, et al. Vit D deficiency in UK south Asian. Osteoporos Int. 2013;24(2):447-88

26. Beaudart C, Buckinx F, Rabenda V, Gillain S, Cavalier E, Slomian J, et al. The effects of vitamin D on skeletal strength, muscle mass, and muscle power: a systematic review and meta-analysis of randomized controlled trials. J Clin Endocrinol Metab. 2014;99(11):4336-45.

27. Grimnes G, Kubiak J, Jorde R. Four months vitamin D supplementation to vitamin D insufficient individuals does not improve muscular strength: A randomized controlled trial. PLoS One. 2019;14(12):e0225600.

28. Jesudason D, Need AG, Horowitz M, O'Loughlin PD, Morris HA, Nordin BEC. Relationship between vitamin D and bone resorption. Bone. 2002;31(2):626-30.

29. Mazidi M, Rezaie P, Vatanparast H. Impact of vitamin D supplementation on C-reactive protein; a systematic review and meta-analysis of randomized controlled trials. BMC Nutr. 2018;4 Available from: https://doi.org/10.1186/s4 0795-017-0207-6.

30. de Cavalcante IGM, Silva AS, Costa MJC, Persuhn DC, Issa CTMI, de Freire TLL, et al. Effect of vitamin D3 supplementation and influence of Bsml polymorphism of the VDR gene of the inflammatory profile and oxidative stress in elderly women with vitamin D insufficiency: vitamin D3 megadose reduces inflammatory markers. Exp Gerontol. 2015;66:10-6.

31. Braithwaite VS, Crozier SR, D'Angelo S, Prentice A, Cooper C, Harvey NC, et al. The effect of vitamin D supplementation on hepcidin, iron status, and inflammation in pregnant women in the United Kingdom. Nutrients. 2019; 11(1):E190.

\section{Publisher's Note}

Springer Nature remains neutral with regard to jurisdictional claims in published maps and institutional affiliations.
Ready to submit your research? Choose BMC and benefit from:

- fast, convenient online submission

- thorough peer review by experienced researchers in your field

- rapid publication on acceptance

- support for research data, including large and complex data types

- gold Open Access which fosters wider collaboration and increased citations

- maximum visibility for your research: over $100 \mathrm{M}$ website views per year

At $\mathrm{BMC}$, research is always in progress.

Learn more biomedcentral.com/submissions 